\title{
Metaphors of Sex in Robert Sylvester Kelly's Selected Songs
}

\section{Metafora Seks dalam Lagu Pilihan Karya Robert Sylvester Kelly}

\author{
Saraswati Eka Ramadhani, Johannes Ananto Prayogo, Nabhan Fuad Choiron* \\ Universitas Negeri Malang, Jl. Semarang No. 5 Malang, Jawa Timur, Indonesia \\ *Penulis korespondensi, Surel: nabhan.fuad.fs@um.ac.id
}

Paper received: 01-03-2021; revised: 15-03-2021; accepted: 31-03-2021

\begin{abstract}
This research investigates metaphors depicting sex used in the lyrics of Robert Sylvester Kelly's selected songs, which most of the songs are known for their outrageously sexual lyrics. In this case, the aims of this research are: (1) to find out metaphors depicting sex, (2) to convey the meaning of the metaphors used by Robert Sylvester Kelly. Using qualitative research design, this research employed Conceptual Metaphor Theory by George Lakoff and Metaphor Identification Procedures (MIP) by Pragglejaz Group in analyzing the data. The findings reveal that there are six kinds of conceptual metaphors depicting sex found in the data. They are (1) sex is violence, (2) sex is eating, (3) sex is journey/adventure, (4) sex is game, (5) sex is a lesson, and (6) sex is insanity. Based on the analysis, sex is violence is the conceptual metaphor used most frequently by Robert Sylvester Kelly in both albums. Through Lakoff and Johnson theory, the meaning can be easier to understand. It shows that each conceptual metaphor has its own meaning or interpretation of sex.
\end{abstract}

Keywords: metaphor, conceptual metaphor, sex

\begin{abstract}
Abstrak
Penelitian ini menganalisis tentang metafora yang menggambarkan seks dalam lirik lagu pilihan Robert Sylvester Kelly, yang sebagian besar lagunya dikenal dengan lirik yang sangat seksual. Dalam hal ini, penelitian ini bertujuan untuk: (1) mengetahui metafora yang menggambarkan seks, (2) menyampaikan makna metafora yang digunakan oleh Robert Sylvester Kelly. Dengan menggunakan desain penelitian kualitatif, penelitian ini menggunakan Teori Metafora Konseptual oleh George Lakoff dan Metaphor Identification Procedures (MIP) oleh Pragglejaz Group dalam menganalisis data. Hasil temuan mengungkapkan bahwa ada enam jenis metafora konseptual yang menggambarkan seks ditemukan dalam data tersebut. Yaitu (1) seks adalah kekerasan, (2) seks adalah makan, (3) seks adalah perjalanan / petualangan, (4) seks adalah permainan, (5) seks adalah pelajaran, dan (6) seks adalah kegilaan. Berdasarkan analisis, seks adalah kekerasan adalah metafora konseptual yang paling sering digunakan oleh Robert Sylvester Kelly di kedua album tersebut. Melalui teori Lakoff dan Johnson, maknanya bisa lebih mudah dipahami. Ini menunjukkan bahwa setiap metafora konseptual memiliki makna atau interpretasi tersendiri tentang seks.
\end{abstract}

Kata kunci: metafora, metafora konseptual, seks

\section{Introduction}

Throughout his career as an American singer, R. Kelly has been charged with sexual abuse involving multiple victims for two decades. In spite of those problems, R. Kelly maintained his amazing careers in R\&B and hip-hop music, earning the nickname "King of $R \& B "$. Indeed, he is a legendary singer and songwriter who is famous for his sexually explicit lyrics. It is written on the news that according to some episodes of the series, his former partners, as well as the victims, mentioned R. Kelly purposely indicated his taboo and salacious behavior in most of his lyrics. This series and the controversy surrounding it remind many viewers and fans of the singer to re-listen to his $\mathrm{x}$-rated song lyrics. 
Sex is a part of delicate issues to discuss or it can be said as a taboo subject. Among those subjects that are traditionally banned from the public or the society, sex gets the strongest interdiction. Therefore, people use implicit terms or indirect reference to talk about sex in present day which created an increase in the number of figurative language which referring sex (Fernandez, 2008). This phenomenon actually is proof that no matter how a subject is forbidden, there is still a need to refer to them in one way or another. Authors who want to raise the issue of sex also experience the needs. The restrictions resulted in many songs and literacy works being banned for being too blunt in several countries. It seems very difficult for authors to talk about sex in their works.

Interestingly, despite all of those problems the proportion of songs with themes of lust has surpassed the proportion of songs with themes of love over the time (Madanikia \& Bartholomew, 2014). Genre of Rap/R\&B contains higher frequencies of sexual content than other genres and a strong correlation between sexual content. According to most of earlier studies, male singers are more likely than female singers to sing songs with sexualized lyrics. Robert Sylvester Kelly is one of the male singers who maintained his remarkable career in sex music. In expressing sexual things in his song lyrics, R. Kelly uses many kinds of figurative language. He put many uncommon expressions that refer to sexual terms by using metaphorical expressions that make the researcher wants to do further studies on the metaphors depicting sex in his several selected sex-themed songs. In fact, he has created new concepts about sex through his crazy and imaginative metaphors referring sex. Most of them deal with violence.

High exposure to music with sexual lyrics associated with real life sexual behavior. Moreover, song lyrics describing degrading sex may be a strong risk factor for early sexual progression in particular way (Primack, et. al, 2009). By understanding the meaning or the conceptualization employed in song lyrics, the listeners can, wisely, sort out sex music they should listen. Since, in fact, prior studies claimed that degrading sex in music containing sexual aggression tend to desensitize individuals to real-life violence related to sex (Primack, et. al, 2009). Therefore, understanding the meaning of sexual metaphors in songs is important for the exposure to popular music that is rapidly increasing than other media messages.

Song discussions are always related to the use of language in the lyrics. Song is one of the forms to utter expressive feelings or thoughts issued regularly in the form of sound. As explained by Oxford Learner's Pocket Dictionary (2008: 261), lyric is the word of a song; it is expressing personal emotion; lyrical is expressing writer's feeling imaginatively and beautifully. The songs we listen to are not merely beautiful language, but the content is often closely related to the writer or the singer. According to the statements by Dallin as cited in Firdaus (2013):

"Lyrics are written as a form of interaction between the writer and the listeners. Most of the time, they carry a message with the purpose of motivating the listeners, at least, to think about it. Such a purpose and form of interaction are embedded in the cultural context of these people, according to their musical preferences, time, etc."

However, the listeners cannot get the pleasure of listening to songs if they don't understand the meaning beneath the lyrics. In making songs and expressing their feelings into lyrics, songwriters use language style. According to Abrams (2000), figurative language is words or expression that deviates from daily speech, from what the speakers apprehend as 
ordinary meaning of words, by using comparison, analogy, and allusion. Figurative language or language style is also explained as one way to express the soul, mind, and personality of the language users through their particular unique ways (Keraf, 2004). Songs usually use figurative language to beautify the lyrics so that the listeners will be more attracted to it. Implicit meanings, like love, anger, sexual things, etc., in songs are expressed mostly by metaphor. In further discussion, the researcher would like to analyze the metaphors in terms of sex as reflected in R. Kelly's songs. By analyzing his songs, we can understand the author's feelings and the messages that are expressed. It can be explored from the analysis by discovering metaphorical expressions and defining each part of the lyrics.

Metaphor is widely used in literature such as in poetry, song lyrics, and novels. Authors use metaphors to illustrate or describe something that cannot be only represented in literal style. Metaphors are often considered as the art of language used to beautify literary works or, in another word, create poetic languages. It means metaphors convey meanings by not using the literal words, phrases, or sentences. Knowles and Moon (2006) stated that metaphor entails the use of the non-literal meaning of a word to refer to something else. They create more specific and vivid visual images of what the author is trying to describe. However, Lakoff and Johnson (1980) explained in their book Metaphor We Live By that metaphors do not only appear to poetic features of languages but they may create realities for us. It is inseparable that metaphor has revealed many facts about how the human mind uses metaphors in daily life. That is directly proportional to the fact that R. Kelly conveyed his concept of sex through the metaphorical expressions he used on his songs. The researcher only found two studies analyzing Robert Sylvester Kelly. Those earlier studies focused on his criminal case and did not discuss his music. However, scholars have thoroughly conducted research on sexual metaphors. Fernandez's (2008) study is the biggest corpus-based study which has ever been conducted on metaphors of sex. His work focused on euphemistic and dysphemistic referring sex used in the society within the framework of conceptual metaphors.

Tsang (2009) described sex as war and eating. This research analyzed sex metaphors found in Hongkong's major local newspaper. The result reveals the relationship of sex metaphors and Chinese culture, also how these metaphors affect the targeted readers' conceptual system, beliefs and behaviors. Terry (2019) develops a study on taboo topics, including sex, in a TV series corpus. It carries out new classification of sex metaphors including sex as religion, teaching, show, politics, and drugs. In 2020, Ojoawo and Akinmade draw attention to sex metaphors on Nigerian hip-hop music. This is the only one study of sex metaphor focus on music that the researcher has found. Their study dividing sex metaphors into sex as a dance, sex as food, and sex as a game. Indeed, scholarship in this area is still limited since society places restrictions on such topics. Sex talks and their negotiations are hardly expressed verbally in public. It prompts the present study to explore how metaphors are used to negotiate sex talks in song lyrics, specifically in Robert Sylvester Kelly's selected songs. This research also intends to examine how metaphor stands as a way to speak about sex. More specifically, the present research intends to find out the kind of conceptual metaphors as well as the meaning of each metaphor in Robert Sylvester Kelly's selected song lyrics.

\section{Method}

The data of this research was obtained from his two albums, "Black Panties" (2013) and "The Buffet" (2015). These two albums are the comeback of Kelly's sexual exaggeration content after his classy and family friendly albums during his darkest time with his child- pornography 
charges. To ease the researcher in collecting the data, the lyrics are accessed through https://www.genius.com. The researcher focused only on sensual romantic story themed songs. In this study, the researcher wanted to know how many sexual metaphors exactly found in lyrics, what types of metaphorical expressions, the meaning, and the source domain of the metaphorical expressions found in R. Kelly's songs. After organizing and preparing the selected songs, the researcher employed the Metaphor Identification Procedure (MIP) to detect metaphorical expressions in each song. Only conceptual metaphors associated with sex were sought by selecting conceptual metaphor with a target domain that was directly related to sex. To identify conceptual metaphor domains, the researcher consulted a compendium of metaphors of sex as detected by Fernandez (2008), Ching and Tsang (2009), and Terry (2019). Using the theory of conceptual metaphor proposed by Lakoff and Johnson (1980), the researcher began to enter into the conceptual mapping theory analysis (Conceptual Mapping Theory) by Lakoff and Johnson. This conceptual mapping theory indicates the source domain, the target domain of the metaphors found, and the meaning of each metaphor found.

After reading all of the data, the researcher categorized it into the list of source domain and target domain conceptual metaphor of sex. "the conceptual domain from which we draw metaphorical expressions to understand another conceptual domain is called source domain, while the conceptual domain that is understood this way is the target domain".

The data was described by using narrative passages and mentioning the chronological context of the metaphors to give a clear explanation about the literal meaning of each conceptual metaphor, especially the source domain of the concept. In the last step, the researcher made the interpretation of the data to capture the idea and explain the deeper meaning of each finding.

\section{Findings and Discussion}

\subsection{Kinds of Conceptual Metaphor in R. Kelly's Song Lyrics}

Nine singles were taken from Robert Sylvester Kelly's 2013 album "Black Panties": "Cookie"; "Marry the Pussy"; "Genius"; "Crazy Sex"; "Physical"; "Every Position"; "Circles"; "Lights Out"; "Tear It Up". There were also six singles analyzed which were taken from his 2015 album "Black Panties": "The Poem"; "Poetic Sex"; "Let's Make Some Noise"; "Marching Band"; "Wake Up Everybody"; "Sextime". The finding shows the conceptual metaphors related to sex found in each song lyrics along with the sample of the lyrics. From that table, there are six different kinds of conceptual metaphors which depicted sex found from fifteen selected songs. The conceptual metaphors found are (1) sex is violence; (2) sex is eating; (3) sex is journey/adventure; (4) sex is game; (5). sex is a lesson; and (6) sex is insanity.

For the first conceptual metaphor, the researcher found 12 data which had the source domain VIOLENCE to interpret SEX indicated by several particular words or phrases: take a stab; hit; TKO; kill; bang; beat; drill; take-down; spank; thriller; tear-off; and tear-up. Sex is violence is the conceptual metaphors that most commonly found in this study. According to Lakoff and Johnson (2008), sex and violence are mostly linked in the American mind via the metaphors of war and physical force. Sex is violence is closely associated with lust and the fact that the metaphorical understanding of lust related to metaphorical understanding of anger. In sex is violence metaphor, the sexual partners are seen not as person to be cared or protected, 
but as opponents to be attacked and overpowered. In most metaphors it is the woman who is metaphorically attacked.

The second conceptual metaphor for sexual matters found in R. Kelly's selected songs is sex is eating indicated by the words or phrases such as, feed, feast, bite, eat, dinner plate, dinner time, meal, buffet, Oreo, and cookie jar. It draws on concepts from the experience of eating. Sex and eating are having a close association with the conventional metaphors as stated by Lakoff in her book Women, Fire, and Dangerous Things: What Categories Reveal About the Mind" 1987, about lust is hunger. Feeling hungry and eating are used to express sexual desire and related actions. Some foods are used to describe sexual organs. In the same vein, Fernández (2015) in his book entitled "Sex in Language: Euphemistic and Dysphemistic Metaphors in Internet Forums" maintained that food represent most body part and also oral sex. It can be said that knowledge and experience of food and eating is linked to the concepts of sexual feeling and practices which one has already experienced.

Spot, private places, address, map, tour, pay visit, scenic route, get lost are the words or phrases used by R. Kelly in written his songs which are belongs to sex is journey/adventure. Semantically, there is no connection between sex and journey. This conceptualization is the result of using the common knowledge we have about journey to describe sex. As Lakoff (1987) argued, a direct reference to sexual topics can be avoided by resorting to the SOURCE-PATHGOAL image schema into which our everyday experience may be organized. Therefore, sexual encounter is understood as a process that has a starting point, an end point, and a time span (Fernández, 2015). Most of the previous researchers had already claimed in love is journey metaphors, in which the lovers are portrayed as travelers on journey and their goals are the destination. However, sex also can be interpreted and systematically conceptualized as a journey. Those who engage in sexual encounters are seen as the travelers, the sexual activity is the journey, and their goal for reaching pleasure or orgasm is the destination.

The researcher found three occurrences of the metaphor sex is game in total. There are two occurrences in "Cookies" song lyrics and one occurrence in "Poetic Sex" song lyrics. The imagery of games and sports are used to hide certain sexual topics which are known as taboo subjects. Kovecses (2004) stated that games are categorized by certain properties for metaphorical purposes. Through conceptual metaphors theory, sex can be described in terms of games. It fits to the target domain, sex, which is also depicted as an entertaining and pleasurable activity. Game is seen as the sexual activity and those who engage in the sexual activities are portrayed as the people playing. It is identified that R. Kelly used the word rollercoaster; throwing-catching; and poker as the metaphors for sex.

Lakoff (1987) argued that the concepts of insane behavior stand for lust action. The argument is the fundamental of the next conceptual metaphor the researcher has found in this study, sex is insanity. In sex is insanity, the metaphor of sex is presented as a state of insanity. Kovecses (1986) said that an insane person is not responsible for his/her. Therefore, this concept actually explains that insanity, including lack of control, obsessions, behaving irrationally etc is described the mental effect experienced during sex arousal. One having sexual encounter is seen as an insane person and feeling during sex as an illness itself. The person who engaged in the sexual activities usually overflowed with lust so that they cannot think rationally and have less control over themselves. The researcher found one occurrence in "Marry the Pussy" song lyrics and another one occurrence in "Lights On" song lyrics. 
The last is sex is lesson. According to the Merriam Webster dictionary, a lesson is defined as something learned through formal learning or experience. A lesson is understood as an exercise or assignment that a person needs to prepare or learn within a given time until that person masters that particular subject. Therefore, the source domain of lesson can be used to describe sex. The researcher has found 7 data representing this type of metaphor in this study indicated by sex trainer; work the pussy out; sex genius; the master; college grad; teach; and first semester. There are two occurrences in "Marry the Pussy", three occurrences in "Genius", and two occurrences in "Every Position". Similar to the image schema that is explained in sex is journey, the schema also can be applied in this conceptual metaphor. Sex is lesson metaphor has the start, the path is the time span for learning, and the goal is to master the lesson. Sex is interpreted as a particular subject where those who lack of experience in doing the sexual activities needs more time to learn and gain more experience. For those who have already gained a good amount of knowledge and skills are considered as masters who are ready to teach others.

\subsection{The Meaning of Metaphors in R. Kelly's Song Lyrics}

A. Sex is Violence

1) "Go to sleep and when we wake up I'ma hit that thing again promise" (Genius, 2013)

2) "Hit it from the back while I'm smoking my cigar" (Tear It Up, 2013)

3) "I'mma break the bed I'mma hit it hard, babe, I'mma pull your hair" (Tear It Up, 2013)

4) "When I hit that you yell out God" (Poetic Sex, 2015)

5) "Cause imma hit it nonstop" "I be hitting it hard from the back till the wall shake" (Sextime, 2015)

In Data $1-5$, the verb hit is showing a striking image of violence involved in a sexual intercourse. Hit it actually simply means copulation. Similar with the word hit, connotations of violence are transmitted by the verb bang, beat, and spank. It does give a negative image of harming or hurting the partner's genitals during sexual intercourse.

6) "Bout to bang on a pussy like throwing up crip" (Cookie, 2013)

7) "Then I beat the pussy till it's blue" (Cookie, 2013)

8) "I spank that pussy like it's so naughty" (Marry the Pussy, 2013)

All those three different terms in Data 6 - 8 have actually shared the same meaning, penetration or copulation. The researcher also found the metaphorical expression in the form of phrases like take a stab, take - down, TKO, and tear-off. These phrases mentioned in the samples below belong to the conceptualization of sexual activities which involve acts of violence.

9) “Your body's so freakin' soft. I can't wait to tear it off" (Genius, 2013)

10) "You gon' make me take you down" (Physical, 2013)

11) "I'mma tear it up then I'mma chop screw it" (Tear It Up, 2013)

12) Imma take a stab at it, ok" (Poetic Sex, 2015)

13) "Ass soft as a feather, I TKO it, Mayweather" (Marching Band, 2015)

From Data $9-13$, sexual intercourse or copulation is seen as an action of defeating the partner. It can specifically be seen from the application of TKO in Data 13. TKO means technical knockout, describing a situation where one player is defeated and unable to continue the fight. 
After all, the terms used as the metaphors contain violence are specifically applied to reach one's sexual objective. It implies that women are conceptualized as the target of the male sexual attack. In the sample below, the expression refers to penetration of the vagina with a penis related with the conceptualization of the tool.

14) "Get in that pussy, drill that pussy" (Marry the Pussy, 2013)

Data 14 indicates that the female partner is attacked by the action of tools which is expressed by drill. This term belongs to sex is violence metaphor since the action of drilling would be painful if it applied literally to human being. It does support the statement from several studies which said that in most metaphors, women are positioned as victims of an attack. Other realizations of the violence metaphors for sex appear with greater emphasis on male domination. It brings more than aggressive and violent actions. The concept represents penis as a weapon and the penetration by penis is represented as the action of killing (see Data $15)$.

15) "I kill that pussy every time, bang bang" (Let's Make Some Noise, 2015)

As seen from Data 16 below, the word thriller used to express brutal and exciting sexual intercourse. Meanwhile, thriller is actually associated with crime and murder. If it is applied in a discussion about sex, it gives an image of violent or even injurious activity done during the sexual intercourse. In addition, it gives a hyperbolic tone for expressing an exciting sexual intercourse.

16) “Let's get scary, let's go thriller" (Crazy Sex, 2013)

B. Sex is Eating

In food imagery, hunger represents sexual desire as stated by Lakoff (1987a) in the conventional metaphor lust is hunger. The word hungry in Data 17 below means that he or she is in need for sex. The adjective hungry is such realization of the metaphor sex is eating associated with love is a nutrient. However, the word feed in the next line seems to complement the word hungry. The verb feed applied in sexual related discussion means the action of fulfilling sexual desire. That leads to the notion that feed or feeding means sexual intercourse itself.

17) "I just can't get enough of your buffet

And I'm so hungry

Baby feed me" (Poetic Sex, 2015)

The source domain eating has been used mostly to talk about the topic of oral sex for a long time. Two samples below (Data 18 \& 19) show that cunnilingus and fellacio are metaphorically represented as the act of eating.

18) "Like an Oreo

I wanna bite it and get inside it" (Cookie, 2013)

19) "Feels so good

you wanna bite something

and I just what you to know that I can take it so bite $\mathbf{m e}$ " (Circles, 2013)

In this study, the researcher found two different sentences using the term bite. In Data 18 , bite refers to cunnilingus and it refers to female genitalia. Since the singer of the song, R. 
Kelly, is a male, the phrase bite me in Data 19 is the metaphorical expression of fellatio. Performing oral sex (cunnilingus or fellatio) is conceptualized by terms in eating source domain since both of the activities share the same component which is the action of taking something into body by the mouth.

\section{0) "I'm feasting on it like the last meal" (Sextime, 2015)}

The verb feasting in Data 20 also refers to cunnilingus. It presents a hyperbolic overtone in the act of eating. It brings to mind the image of a person eating a large amount of sumptuous food. As described before that desire is represented as hunger and the act of fulfilling the desire is expressed as eating, it generates a concept that the sexual object is food, or more precisely, appetizing food (Kovecses, 2004). The sample below mentioned the word buffet which refers to the female body which is close to perfect because it provides everything.

\section{1) "I just can't get enough of your buffet" (Poetic Sex, 2015)}

It is also related to the metaphors of women as desserts by Hines $(1996,2000)$. The realizations of women as dessert depict women as sweet objects to be eaten. In this study, the researcher found that the female's genital part is represented as a cookie jar. The word cookie is not merely a realization of appetizing food. However, it derives from a beautiful black girl. The researcher concluded the meaning from watching the "Cookie" music video.

Another food conceptualization of male and female genital's part was found in "The Poem" lyrics. The song is mainly talk about sex in culinary metaphorical expression. The sentence below represents copulation as a tasty dessert, where the male genital is represented as jelly and the female genital as pastry (see Data 22).

22) "I'm talkin' my jelly in your pastry" (The Poem, 2015)

A research conducted by Refinetti (2005) revealed that most sexual encounters take place at night around bedtime. It is a common knowledge, both of having sex and dinner is done by night time. Therefore, it does generate conceptualization of sex as dinner.

23) "Let's wake up it's dinner time, turn up" (Cookie, 2013)

24) "Girl put your body on a dinner plate" (Poetic Sex, 2015)

The word dinner time in Data 23 means time for sex. The sentence means that it is the time for having sex and the female partner needs to wake up. Whereas, in Data 24, dinner plate means a place or perhaps bed to put the female's body. A plate is a place to serve the food that is going to be eaten.

C. Sex is Journey

In the source domain journey, the lovers are seen as the travelers, the sexual encounter is the action of taking a journey, and particular parts of the female body are the destination he or she wants to visit. The sample below shows that a sexual encounter or the copulation is represented by the term tour. In addition to the word tour, sexual encounter is metaphorically expressed by the phrase pay visit as shown in Data 26.

25) "I'm hitting every spot on your map, that's me going on tour" (Cookie, 2013)

26) "I wanna pay a visit to the private places on you, baby" (Circles, 2015) 
Both of the samples above mention female genitals by representing them as particular locations that will be explored on a journey. Parts of the female genitalia are described in terms of "spot" and "private places". On a trip, someone needs a map that will show a direction to reach the destination. Therefore, map in Data 25 means guidance in doing sexual encounters. The male partner had already reached every private part on the female body by following the guidance he had on the map.

\section{7) "Pussy my address. Just being honest}

And they say home is where the heart is" (Poetic Sex, 2015)

In Data 27 above, the female genital is metaphorically expressed by the term address. The message underlie in this sentence is that the female body, especially the female genital part, is the end of the journey. It also means the female genital is considered something important and special. Indeed, also has the meaning of the final or the end of everything.

\section{8) "I take my time in it, that's the scenic route" (Marry the Pussy, 2013)}

The term scenic route in Data 28 means a way that is not the fastest but that has beautiful scenery. Therefore, the sentence means that the male partner chooses to do the sexual intercourse slowly and not in a hurry to enjoy his journey. After all, the researcher also combined adventure in this metaphor because both adventure and journey have a close relationship. Adventures portray a sexual experience with an element of risk. The term get lost is transmitted in the sample below reveals an image of the challenge or unexpected risk involved in sexual encounter.

29) "I wanna get inside with you baby and get lost" (Wake Up Everybody, 2015)

D. Sex is game

30) "You throwing ass, I'm catching it, the neighbors keeping score" (Cookie, 2013)

In "Cookie" song lyrics, one of the connotations of game is transmitted by the term throwing - catching. This term is a basketball term which is often used as a metaphorical expression for sex. Followed by the sentence "the neighbors keepin'score" gives more certainty that in this sentence sex is conceptualized as a basketball game. Throwing - catching have a definition of basic moves in basketball that are performed by players back and forth. In the sentence above, throwing and catching referencing penetration or copulation.

31) "Ooh she rollercoaster'd on it" (Cookie, 2013)

The use of verb rollercoaster is another form of realization of the source domain game. Rollercoaster is known as a ride in the form of a fast train that goes up and down very steep slopes and around very sudden bends. Riding roller coasters is often associated with adrenaline rush activities. In the sentence above, the action of the riding roller coaster resembles sexual activity. Indeed, there is one kind of positions in having sex that makes the female partner sits on top of the man and goes up and down while doing the penetration. It is also portray an image of the adrenaline rush that is felt in sexual intercourse.

32) "It's a poker and I got you all in" (Poetic Sex, 2015) 
The lyric in Data 32 above, both poker and sex shared same components in which a person makes a lot of efforts, even bluff and cheats, to win what they want. All in means that a player is committed to put everything he or she got into the game, the sexual intercourse. When a player is all-in, the player cannot do anything else and must focus on winning the game. Some arguments stated that comparing sex and poker once again demonstrates male dominance and makes women treated as objects.

E. Sex is Insanity

This concept is found in Kelly's song titled (1) Marry The Pussy and (2) Lights On:

33) "I drive that pussy crazy, that's my Bugatti" (Marry The Pussy, 2013)

34) "Baby leave them lights and Imma fuck your fucking brains out" (Lights On, 2013)

The singer in Data 33 is trying to make the pussy insane. The line means that the one involved in sexual intercourse can cause a particular mental illness. However, Data 34 suggests an unreal and illogical state of mind where the brain can come out the head. It shows how people who are having sexual activities will cause the partner lack of control over their state of mind. Both of the samples suggest that the feeling or pleasure obtained from having sexual intercourse is an illness itself.

F. Sex is Lesson

35) "Girl tonight you're lying with a sex genius" (Genius, 2013)

36) "Sex trainer, I work pussy out" (Marry the Pussy, 2013)

The use of terms like teach, first semester, trainer, genius, college grad, and master introduce a quiet contrast between source domain game which is presumably a pleasurable activity. On the two samples above the terms sex trainer and sex genius indicate a lustful man who has great skills and knowledge of sex. As the definition of master and genius which are associated with education, it appears a striking image that sex is represented as a lesson where those who engage in a sexual encounters need to learn so that they can be good at it. Similar with genius and trainer, conceptualization of sex as lesson is transmitted by the words master and college grad.

37) "Whoa tell me I'm the master baby" (Genius, 2013)

38) "Imma college grad girl I got my degree I'm ahead of my class girl you met the real thing" (Genius, 2013)

39) "And woah, if you don't know Imma teach ya First semester in my bedroom, now I'm about to freak ya" (Every Position, 2013)

In Data 37, R Kelly wrote a more specific metaphorical expression for sex by including the level of education. A college grad expressed a lustful adult male who has graduated in studying sex. As shown by Data 39, the reliable one is ready to teach the beginner. The amateur in sexual activities is considered to be in the first semester so he or she needs more time to study. Indeed, the implication of using lessons as the source domain shows that a sexual activity is conceived as a serious action which requires commitment and sincerity for all participants involved. 


\section{Conclusion}

The researcher would like to draw a conclusion on the result of the research findings that have been investigated and analyzed in the previous chapter. After analyzing the data, the researcher found that it is true that metaphors create more specific and vivid visual images of what the author is trying to describe. This study has discovered the conceptual metaphors which depict sex and its meaning in Robert Sylvester Kelly's song lyrics. Based on the research problems in this research, there are 6 conceptual metaphors depicting sex found in fifteen song lyrics from his two albums, "Black Panties" and "The Buffet". Those are sex is violence, sex is eating, sex is journey/adventure, sex is game, sex is a lesson and sex is insanity. The meaning of metaphors revealed from the analysis process shows that the concept of sex which Robert Sylvester Kelly shared with the listeners have a violent aspect, common aspect as eating, learning, and also playing. One conceptual metaphor that is frequently used by Robert Sylvester Kelly in both of the albums is sex is violence. It can be concluded that all of the source domains found in the conceptual metaphors of sex in the lyrics of Robert Sylvester Kelly's songs are the result of how he subconsciously comprehend the concept of sex.

After analyzing the data and summarizing the conclusion, there are some recommendations which are addressed to other researchers who are interested in conducting investigations in similar topics. Future researchers may resort to Robert Sylvester Kelly's songs from different albums for so many of his songs talking about sex. Since this research only focuses on conceptual metaphors of sex in song lyrics, future researchers can do further research analyzing other data sources also study conceptual metaphors outside the domain of sex.

\section{References}

Abrams, M.H. (2000). The Norton anthology of English literature. New York: Norton.

Ching, S. \& Tsang, Y. (2009.) Metaphor, culture and conceptual systems: A case study of sex metaphors in a Hong Kong Chinese newspaper. LCOM Papers, 2.1-16.

Fernandez. C P. (2008). Sex-related euphemism and dysphemism: An analysis in terms of conceptual metaphor theory.

Firdaus, E.A. (2013). Textual meaning in song lyrics. Bandung: Indonesia University of Education.

Hines, C. (1996). What's so easy about pie? The lexicalization of a metaphor", in Goldberg, Adele (ed.): Conceptual Structure, Discourse and Language, Stanford, California, CSLI Publications, 189-200.

Hines, C. (2000). Rebaking the pie: The 'WOMAN AS DESSERT' metaphor”, in Bucholtz, Mary/Liang, Anita/Sutton, Laurel (edd.): Reinventing Identities: The Gendered Self in Discourse, New-York and Oxford, Oxford University Press, 145-162.

Keraf, G. (2004). Komposisi: Sebuah pengantar kemahiran bahasa. Ende: Nusa Indah.

Knowles, M., \& Moon, R. (2006.) Introducing metaphor. London and New York: Routledge.

Kovecses, Z. (1986). Metaphors of anger, pride and love: A lexical approach to the structure of concepts. Amsterdam: John Benjamins.

Kovecses, Z. (2004). Metaphor and emotion: Language, culture, and body in human-feeling. Cambridge: Cambridge University Press.

Kovecses, Z. (2010). Metaphor: A practical introduction (2nd Ed.). Oxford: Oxford University.

Lakoff, G. \& Johnson, M. (1980). Metaphor we live by. Chicago: University of Chicago Press.

Lakoff G \& Johnson, M. (2008). Women, fire, and dangerous things: What categories reveal about the mind. Chicago: University of Chicago press. 
Madanikia, Y. \& Bartholomew, K. (2014). Themes of lust and love in popular music lyrics from 1971 to 2011. DOI: https://doi.org/10.1177/2158244014547179.

Ojoawo, A. \& Akinmade, A. (2020.) Sex sells: Sexual metaphors in selected Nigerian hip-hop music, Muziki: Journal of Music Research in Africa, 17(1). DOI: 10.1080/18125980.2019.1635517.

Primack, B. A., Douglas, E. L., Fine, M. J., \& Dalton, M. A. (2009). Exposure to sexual lyrics and sexual experience among urban adolescents. American journal of preventive medicine, 36(4), 317-323. https://doi.org/10.1016/j.amepre.2008.11.011.

Refinetti, R., (2005). Time for sex: Nycthemeral distribution of human sexual behavior. Journal of Circadian Rhythms, 3(4). DOI: http://doi.org/10.1186/1740-3391-3-4

Terry, A. (2019). The representativeness of the metaphors of death, disease, and sex in a TV series corpus. Cognitextes, 19. DOI: https://doi.org/10.4000/cognitextes.1730

Tsang, S. C. Y. (2009). Metaphor, culture and conceptual systems: A case study of sex metaphors in a Hong Kong Chinese newspaper. Language and Communication Papers, 2, 1-16. 